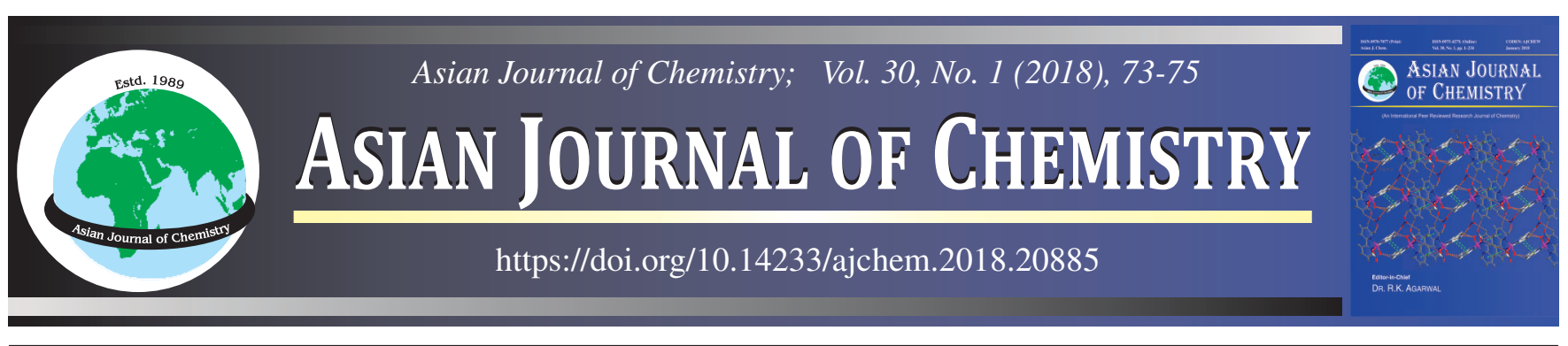

\title{
Determination of Palladium Content in Nebivolol HCl Bulk Drug by ICP-OES
}

B. SIVA SAI KIRAN ${ }^{*}$ and S. RAJA

GITAM Institute of Pharmacy, GITAM University, Visakhapatnam-530 045, India

*Corresponding author: E-mail: sivasaikiran143@gmail.com

\begin{abstract}
The aim of the present work is to develop a validated analytical method for the determination of palladium content in nebivolol $\mathrm{HCl}$ bulk drug by inductive coupled plasma-optical emission spectroscopy (ICP-OES). Samples were analyzed after a preparation of sample solution by dissolving in suitable diluents of nitric acid along with hydrogen peroxide. In the present method, RF power of 1500 watts, plasma flow of $15 \mathrm{~L} / \mathrm{min}$, nebulizer flow of $0.7 \mathrm{~L} / \mathrm{min}$ and plasma view at axial mode were used. The wavelength was monitored at $340.46 \mathrm{~nm}$. This allowed a rapid determination of amount of palladium metal present in nebivolol bulk drug. The developed method was validated according to ICH guidelines. Calibration curve for palladium determination were conducted in the range of $10-100 \mu \mathrm{g} / \mathrm{mL}$. The correlation coefficient for palladium was found to be 0.999970 which indicates good linearity. Recovery rates for palladium were in the range of 86.66-102.66. Limit of detection (LOD) and limit of quantification (LOQ) present in the sample was found to be $3 \mu \mathrm{g} / \mathrm{mL}$ and $10 \mu \mathrm{g} / \mathrm{mL}$, respectively. The method developed and validated was selective, sensitive, rapid and capable of detecting palladium in the presence of other elements in bulk drugs.
\end{abstract}

Keywords: Nebivolol HCl, Inductive coupled plasma-optical emission spectroscopy, Metal analysis.

\section{INTRODUCTION}

Nebivolol is a $\beta 1$ receptor blocker with nitric oxide potentiating vasodilator effect used in treatment of hypertension and in Europe, also for left ventricular failure [1]. It is highly cardio selective under certain circumstances. $\beta$-Blockers help patients with cardiovascular disease by blocking $\beta$ receptors, while many of the side-effects of these medications are caused by their blockade of $\beta 2$ receptors [2]. Nebivolol is unique as a $\beta$-blocker. Unlike carvedilol, it has a nitric oxide potentiating vasodilator effect $[3,4]$. Along with labetalol, celiprolol and carvedilol, it is one of four $\beta$-blockers to cause dilation of blood vessels in addition to effects on heart [5]. However, recent studies question the clinical relevance of this property to Nebivolol's efficacy $[6,7]$.

Various analytical techniques were employed for the determination of inorganic metal impurities include titration, ion-exchange chromatography, capillary electrophoresis and spectroscopic techniques like flame photometry, flourimetry, atomic absorption spectroscopy and inductive coupled plasma. Among the above mentioned techniques, inductive coupled plasma is a versatile tool for detection and quantification of elements in accurate manner and it works on the basis of atomic spectrometry. Inductive coupled plasma also further include 2 types which are ICP-optical emission spectroscopy and ICP- mass spectroscopy. Most specifically, ICP-OES is emission spectrometric technique that exploits the fact that excited atoms emit energy at a given wavelength as the electrons return to their ground state from excited state. A given element emits energy at specific wavelengths peculiar to its chemical nature. The intensity of the energy emitted at that wavelength is proportional to the amount of that element in the analyzed sample. When compared with the other techniques ICP-OES has an additional advantage in terms of detection limits (where it can detect to a concentration range of ppm or ppb) and a rapid analysis. In ICP-OES, sample experiences temperature estimated to be in the vicinity of $10,000 \mathrm{~K}$. These results in atomization and excitation of even most refractory elements with high efficiency so that detection limits for these elements with ICPOES can be well over and order of magnitude better than the corresponding values of other techniques [8].

The titration methods are not accurate whereas ion exchange chromatography and capillary electrophoresis stabilization is a time taking process and sensitivities are low when compared to ICP-OES. For the above reasons, ICP-OES has become a tool of choice for estimating metals. Literatures revealed that few methods like determination of metals in food samples like vinegar [9], environmental samples (soil and drinking water) [10-16], potato chips [17], honey [18] eliphos tablets [19] and escitalopram oxalate bulk drug [20] are reported. 
This paper describes the methodology and validation procedure by ICP-OES for determination of metals in nebivolol bulk drug and the method was validated according to $\mathrm{ICH}$ (Q2R1) guidelines.

\section{EXPERIMENTAL}

Nitric acid (analytical grade) from Merck, India, MilliQ water and palladium metal standard of certified reference material were used. The nebivolol $\mathrm{HCl}$ was obtained as a gift sample from Varun Herbals, India. The method development and validation was performed by using ICP-OES and $3 \%$ nitric acid is used as diluent.

ICP-OES conditions: The RF power used was $1300 \mathrm{~W}$, plasma flow was $13 \mathrm{~L} / \mathrm{min}$, auxiliary gas flow was kept at 0.2 $\mathrm{L} / \mathrm{min}$, nebulizer flow was kept at $0.7 \mathrm{~L} / \mathrm{min}$, and pump rate was kept at $1 \mathrm{~mL} / \mathrm{min}$. Palladium was monitored at wavelength $340.458 \mathrm{~nm}$. Plasma view was in axial view. Three replicates were performed.

Preparation of sample: The sample preparation was done by using Microwave digester. Weighed $200 \mathrm{mg}$ of sample and added $5 \mathrm{~mL}$ of nitric acid and $2 \mathrm{~mL}$ of $\mathrm{H}_{2} \mathrm{O}_{2}$ dropwise, after completion of digestion cool the vessel and transferred it into $20 \mathrm{~mL}$ volumetric flask and made up to volume with diluent.

Preparation of standard: Preparation of palladium stock standard solution $(10 \mu \mathrm{g} / \mathrm{mL})$, palladium standard (certified reference material) with 1000 ppm was obtained and labeled as reference standard. Further suitable aliquots were prepared from the standard stock solutions with the concentrations of $10,30,50,70$ and $100 \mu \mathrm{g} / \mathrm{mL}$.

\section{RESULTS AND DISCUSSION}

The main objective of the study was to develop a suitable ICP-OES method to quantify palladium content present in nebivolol $\mathrm{HCl}$. During the method development, palladium standard prepared of any working concentration was monitored at different possible emission lines of 338.57, 340.46 and $345.85 \mathrm{~nm}$ by aspirating the solution. Among these emission lines at applied target RF power of $1500 \mathrm{~W}$ the response for palladium was evaluated. The response of palladium was prominent at $340.46 \mathrm{~nm}$. Moreover, the baseline was to be good at above stated wavelengths compared to other emission lines of elements. The possible inferences were not observed at this emission lines. The method was optimized at these wavelengths during method development. To get better sensitivity plasma view mode was selected as axial. As this mode is much larger than that viewed by normal radial or normal size on ICP resulting higher intensity for elements.

Specificity: Prepared the sample one spiked sample (sample spiked with $100 \%$ standard solution) as per the method and analyzed. The obtained results are reported in Table-1. An

\begin{tabular}{lc}
\multicolumn{2}{c}{ TABLE-1 } \\
SPECIFICITY \\
\hline \multicolumn{1}{c}{ Element } & Palladium \\
\hline Element content in controlled sample (ppm) & - \\
Element spiked amount (ppm) & 0.05 \\
Recovery amount (ppm) & 0.049 \\
Recovery (\%) & 98 \\
\hline
\end{tabular}

acceptance criterion for specificity as per USP is no interference is observed with test sample.

Linearity: Linearity was evaluated by preparing a linear series of standard solutions of palladium in the concentrations range from $L O Q$ level to $150 \%$ level of specification level. From the linear solutions, correlation co-efficient, $\mathrm{Y}$ intercept, slope were calculated and thus the linear relationship of concentration versus counts was verified over the range specified. The correlation coefficient for palladium was found to be 0.999970 which indicates good linearity. The results are reported in Table-2.

\begin{tabular}{cc}
\multicolumn{2}{c}{ TABLE-2 } \\
LINEARITY \\
\hline Statistical analysis & Observation \\
\hline Slope & 125.5 \\
Y-intercept & 42.78 \\
Correlation coefficient & 0.999970 \\
\hline
\end{tabular}

Limit of detection (LOD) and Limit of quantification (LOQ): Linear series of palladium standard solutions was prepared in the concentration range from $0.01 \mathrm{ppm}$ to $0.1 \mathrm{ppm}$ and a calibration curve is developed and calculate the corelation coefficient. The LOD and LOQ were calculated and the LOD and LOQ levels are found to be as LOD $=3 \mathrm{ppb}$ and LOQ $=10$ ppb.

Precision: The precision of method was checked by analyzing six individual preparations of sample as per the test method and prepared six individual spike samples (at $100 \%$ level). The \% RSD was found to be within the specification (\% RSD should not be more than $5 \%$ ). The system precision was checked by analyzing six replicates of palladium standard solution (100\% level). The concentration of element for each replication was calculated by using the calibration standards (Tables 3 and 4).

Accuracy: Sample solutions were spiked with palladium at LOQ level, $100 \%$ level and $200 \%$ level with respect to sample concentration. Each spiked solution was prepared in triplicate and aspirated. The recovery of palladium was calculated against the standard working concentration (Table-5).

Ruggedness: The recovery levels tested in (Analyst-1) were again carried out in Analyst- 2 using same instrument. The recovery values were found to be comparable.

\begin{tabular}{|c|c|c|c|c|c|c|c|c|}
\hline \multirow{3}{*}{ Sample } & \multicolumn{6}{|c|}{$\begin{array}{c}\text { TABLE-3 } \\
\text { SYSTEM PRECISION VALUES }\end{array}$} & & \\
\hline & \multicolumn{6}{|c|}{ Repetitions } & \multirow{2}{*}{\multicolumn{2}{|c|}{ Results }} \\
\hline & 1 & 2 & 3 & 4 & 5 & 6 & & \\
\hline $\begin{array}{l}\text { Palladium } \\
0.05 \mathrm{ppm}\end{array}$ & $0.050 \mathrm{ppm}$ & $0.050 \mathrm{ppm}$ & $0.050 \mathrm{ppm}$ & $0.049 \mathrm{ppm}$ & $0.048 \mathrm{ppm}$ & $0.051 \mathrm{ppm}$ & $\begin{array}{c}\text { Mean } \\
\text { SD } \\
\text { RSD }(\%)\end{array}$ & $\begin{array}{c}0.050 \\
0.0009 \\
1.74\end{array}$ \\
\hline
\end{tabular}




\begin{tabular}{|c|c|c|c|c|c|c|c|c|}
\hline \multirow{3}{*}{ Sample } & \multicolumn{6}{|c|}{$\begin{array}{c}\text { TABLE-4 } \\
\text { METHOD PRECISION VALUES }\end{array}$} & & \\
\hline & \multicolumn{6}{|c|}{ Repetitions } & \multirow{2}{*}{\multicolumn{2}{|c|}{ Results }} \\
\hline & 1 & 2 & 3 & 4 & 5 & 6 & & \\
\hline $\begin{array}{l}\text { Palladium } \\
\text { ppm }\end{array}$ & $0.051 \mathrm{ppm}$ & $0.051 \mathrm{ppm}$ & $0.050 \mathrm{ppm}$ & $0.051 \mathrm{ppm}$ & $0.051 \mathrm{ppm}$ & $0.050 \mathrm{ppm}$ & $\begin{array}{c}\text { Mean } \\
\text { SD } \\
\text { RSD }(\%)\end{array}$ & $\begin{array}{c}0.0505 \\
0.0005 \\
0.990099\end{array}$ \\
\hline
\end{tabular}

\begin{tabular}{ccccc}
\multicolumn{5}{c}{ TABLE-5 } \\
ACCURACY OF PALLADIUM \\
\hline $\begin{array}{c}\text { Spike } \\
\text { level (\%) }\end{array}$ & $\begin{array}{c}\text { Amount } \\
\text { added } \\
(\mathrm{ppm})\end{array}$ & $\begin{array}{c}\text { Amount } \\
\text { recovered } \\
(\mathrm{ppm})\end{array}$ & $\begin{array}{c}\text { Recovery } \\
(\%)\end{array}$ & $\begin{array}{c}\text { Mean } \\
\text { recovery } \\
(\%)\end{array}$ \\
\hline $\begin{array}{c}\text { LOQ level } \\
\text { Sample }\end{array}$ & 0.01 & 0.090 & 90 & \\
& 0.01 & 0.090 & 90 & 86.66 \\
\hline \multirow{2}{*}{100} & 0.01 & 0.080 & 80 & \\
& 0.05 & 0.051 & 102 & \\
& 0.05 & 0.052 & 104 & 102.66 \\
\hline \multirow{2}{*}{200} & 0.05 & 0.051 & 102 & \\
& 0.10 & 0.097 & 97 & \\
& 0.10 & 0.097 & 97 & 97.00 \\
\hline
\end{tabular}

Sample analysis: The previously prepared sample was aspirated in the instrument, the concentration of palladium was found to be $1 \mathrm{ppm}$.

\section{Conclusion}

A validated and accurate ICP-OES method has been developed to estimate palladium content in nebivolol drug. The method is selective and is capable to quantitate Palladium in the presence of other trace elements. The method has been validated in terms of specificity, precision, linearity, accuracy and limit of detection and quantification. The validated method can be used to estimate elements not only in nebivolol but also in other drug substances.

\section{REFERENCES}

1. H. Ryakala, S. Dineshmohan, A. Ramesh and V.R.M. Gupta, J. Drug Deliv., Article ID 827859 (2015); https://doi.org/10.1155/2015/827859

2. R.A. De Boer, A.A. Voors and D.J. van Veldhuisen, Expert Opin. Pharmacother, 8, 1539 (2007); https://doi.org/10.1517/14656566.8.10.1539.

3. M.J. Tafreshi and A.B. Weinacker, Pharmacotherapy, 19, 974 (1999); https://doi.org/10.1592/phco.19.11.974.31575.
4. E. Agabiti Rosei and D. Rizzoni, Drugs, 67, 1097 (2007); https://doi.org/10.2165/00003495-200767080-00001.

5. R. Weiss, Vasc. Health Risk Manag., 2, 303 (2006); https://doi.org/10.2147/vhrm.2006.2.3.303.

6. G. Bakris, J. Cardiovasc. Pharmacol., 53, 379 (2009); https://doi.org/10.1097/FJC.0b013e31819fd501.

7. T. Münzel and T. Gori, J. Am. Coll. Cardiol., 54, 1491 (2009); https://doi.org/10.1016/j.jacc.2009.05.066.

8. C.B. Boss and J.F. Kenneth, Concepts, Instrumentation and Techniques in Inductively Coupled Plasma Optical Emission Spectrometry, Bridgeport Avenue Shelton, CT: Perkin Elmer (2004).

9. A.A. Bayizit and M. Tarun, Not. Bot. Hort. Agrobot. Cluj, 38, 64 (2010).

10. V. Nikolaya, O. Veleva, S. Velichkov and N. Daskalova, J. Spectrosc., Article ID 505871 (2013); https://doi.org/10.1155/2013/505871.

11. Y. Yamini, M. Rezaee, A. Khanchi, M. Faraji and A. Saleh, J. Chromatogr. A, 1217, 2358 (2010); https://doi.org/10.1016/i.chroma.2009.11.046.

12. M. Bettinelli, G.M. Beone, S. Spezia and C. Baffi, Anal. Chim. Acta, 424, 289 (2000); https://doi.org/10.1016/S0003-2670(00)01123-5.

13. M. Rezaee, Y. Yamini, A. Khanchi, M. Faraji and A. Saleh, J. Hazard. Mater., 178, 766 (2010); https://doi.org/10.1016/j.jhazmat.2010.02.006.

14. C. Huang, B. Hu and Z. Jiang, Spectrochim. Acta B At. Spectrosc., 62, 454 (2007); https://doi.org/10.1016/j.sab.2007.04.012.

15. S.L. Ferreira, A.S. Queiroz, M.S. Fernandes and H.C. dos Santos, Spectrochim. Acta B At. Spectrosc., 57, 1939 (2002); https://doi.org/10.1016/S0584-8547(02)00160-X.

16. M. Faraji, Y. Yamini, A. Saleh, M. Rezaee, M. Ghambarian and R. Hassani, Anal. Chim. Acta, 659, 172 (2010); https://doi.org/10.1016/i.aca.2009.11.053.

17. M.A. Al-Rajhi, J. Anal. Sci. Methods Instr., 4, 46 (2014); https://doi.org/10.4236/jasmi.2014.42007.

18. M.R.F. Tehrani, A. Shamsai and M. Vossughi, J. Environ. Health Sci. Eng., 13, 1 (2015);

https://doi.org/10.1186/s40201-015-0157-3.

19. V.V. Vallapragada, G. Inti and J.S. Ramulu, Am. J. Anal. Chem., 2, 718 (2011); https://doi.org/10.4236/ajac.2011.26082.

20. V. Mamatha and J. Kumar Raja, J. Adv. Pharm. Edu. Res., 3, 516 (2013). 